\title{
An Analysis on Public Policies in Universities' Obligation of Ensuring Students' Safety
}

\author{
Zeng Zhen ${ }^{1}$ \\ ${ }^{1}$ Human Resources Department, Southwest University, Chongqing 400716, China. \\ Correspondence: Zeng Zhen, Human Resources Department, Southwest University, Chongqing 400716, China.
}

Funds: This paper was the research achievement of An Study on Universities' Obligation of Ensuring Students' Safety on the Practice of Chongqing (SWU1009026) which is supported by the Fundamental Research Funds for the Central Universities.

Received: September 17, 2014

Accepted: September 30, $2014 \quad$ Available online: October 8, 2014

doi:10.11114/ijsss.v2i4.544

URL: http://dx.doi.org/10.11114/ijsss.v2i4.544

\begin{abstract}
It is claimed in Britain and U.S's tort laws that obligation and special relationship is by nature a manifestation of public policies. Therefore, when analyzing universities' obligation of ensuring students' safety, the court takes public policy into consideration: predictability, the nature and type of risks or damages, adjacency, burden of universities, morality, prevention against future damages, the insurance factor and so on. Reflected in the tort laws, public policy is actually a method balancing social interests. Since there is no clear rule on whether universities should be committed to guaranteeing students' safety, the experience of Britain and U.S. should be referred to by China.
\end{abstract}

Keywords: Special relationship, Safety ensuring obligation, Tort liability, Public Policies

\section{Introduction}

Along with the reforms in China's higher education administration system, the scale of universities and colleges has been greatly expanded. It is revealed in the data in the Statistical Bulletin of National Education Development in 2012 issued by China's Education Bureau on August 16, 2013, there had been 2790 universities and colleges by the end of 2012 , reaching a scale of 33,250,000 students and a gross higher education rate of $30 \%$. However, with such a popularity of higher education, it is more likely for students to suffer from infringement. In increasing tort litigations initiated by college students, some questions have aroused people's attention. Are their universities obliged to ensuring students' safety? Can students demand that their universities should assume the tort liability due to their failure in safety ensuring obligation? What are the factors for the court to consider when dealing with universities' obligation? The above questions are seldom mentioned among Chinese scholars. Comparatively, British and American scholars have gone farther, which lay the basis for the analysis in this article.

\section{The Nature of Obligation and Special Relationship}

\subsection{Safety Ensuring Obligation and Special Relationship}

Safety ensuring obligation generally refers to the operator's obligation of ensuring consumers' personal and property safety according to the law, an important basic factor of which is special relationship. Such relationship can be divided into two types: the special relationship leading to controlling obligation, which aims at the infringer, and the one related to protective obligation, which aims at the victim. According to Article 315 in USA Tort Retelling ( $2^{\text {nd }}$ Edition), the doer has no obligation of preventing the third party's damaging action by controlling him unless there is special relationship between them and such relationship endows the doer the controlling obligation or unless there is special relationship between the doer and another party and such relationship gives him the right to demand the doer's protection. Obviously, with special relationship lying between the doer and the third party, the doer has the obligation of protecting the third party from infringement. Accordingly, he has to take the responsibility for the third party's suffering from infringement due to his failure in fulfilling the obligation.

In America's tort law, instead of a specialized law system, universities' safety ensuring obligation mainly falls into the research on negligence tort. But due to the existence of American universities far previous to the application of the negligence tort theory, theoretical proofs for its universities' safety obligation have undergone a change from the substituting parent theory to the negligence tort theory. Previous to the middle and late 1960s, with the definition of the 
adult age of 21 years old in American law, it was laid down that universities had the responsibility of taking care of their students like their parents since the majority of them fell into juveniles. If schools had intentional or negligent errors in protecting students' personal or property safety, they had to take the infringement duty, which was called the substituting parent theory. Generally speaking, with such theory, the judge was not liable to support students in their legal proceedings against their schools. Actually, despite the duty of taking care of students like their parents mentioned in this theory, this theory serves universities more than students since general laws do not lay down parents' responsibility for children's safety. For universities, this is a right instead of an obligation.

In the modern age, the negligence tort theory serves as the main theoretical source for the American court, which, putting obligation to its core, is mainly used to identify universities' obligation and duty for students. In the negligence tort liability, whether the accused should assume the liability is determined by whether their action complies with their obligation and whether they bring about any unreasonable risks. According to the theory of "no obligation, no liability", if the judge denies the accused's obligation of ensuring the accuser's safety, there is no proof for the accused's tort liability as well. Meanwhile, according to the theory of "no negligence, no liability", even if the accused has the obligation of ensuring the accuser's safety, he has the tort liability only when he has negligence actions. Therefore, it comes first when dealing with universities' tort cases to decide which principle is to be followed in taking the obligation of ensuring students' safety.

The safety ensuring obligation is by nature a duty of care as an active role, the violation of which leads to tort liability. Meanwhile, since all issues related to tort liability are a common issue of public policies, such issues have to come to public policy for solution. Accordingly, public policy factors have to be taken into consideration when we analyze universities' safety ensuring obligation. It is shown in some cases in British and American courts that the court denies that there is some special relationship which endows universities with the obligation of ensuring students' safety while it also turns to other relationship patterns in traditional tort laws to search for some kind of special relationship to make such obligation reasonable, hence leading to a parallel pattern of "having no obligation" and "having obligation". A failure to reach an agreement on whether there is special relationship between them is attributed to the fact that different pubic policy factors are taken into consideration when different courts deal with the above cases.

\subsection{Public Policy}

Since all issues related to tort liability are a common issue of public policy, the judge will give a comprehensive consideration about various public policy factors when confirming the safety ensuring obligation, such as whether the accused has a sensible thinking ability, whether he predicts possible harm or whether he takes proper measures and so on. Even in a case with a confirmed obligation, the judge will consider public policies when deciding the range and extent of the liability in order to achieve the balance between the interests of both sides, such as whether there is any counterplea or limitation about it. After the application of public policies in the safety ensuring obligation, the liability of the accused has been lessened a lot, hence encouraging positive actions, exerting the guidance of laws and therefore promoting social development. According to British and American tort laws, obligation and special relationship is by nature a manifestation of public policy. Currently in U.S., a premise has been agreed on for general obligation issues, that is, the obligation is not sacred by itself but an expression for a comprehensive consideration of the public policy leading to the accuser's access to protection. Therefore, compared with "special relationship", the expression of "obligation" has no much special connotation since both explore some contents of the same issue: whether and how the law regulates the activities and actions among people. Social reforms and scientific development have made our activities more interdependent, bringing about changes in our interpersonal relationships and calling for corresponding adjustment in laws. Some relationships considered insignificant in the past may be vital in current complex society and call for confirmation of possible risks.

\section{Public Policy Factors Considered by the Court in Universities' Safety Ensuring Obligation}

British and American courts give much consideration to public policy when dealing with obligation and special relationship. Similar to the factors in other tort litigation cases, the public policy factors in universities' security ensuring obligation mainly include the following aspects.

\subsection{Predictability}

In British and U.S., predictability is generally taken as the primary factor. It is believed by the court that predictability applies to two aspects: on one hand, universities should prevent predictable risks; on the other hand, they cannot prevent unpredictable risks in an unreasonable way since it is students themselves that serve as the best role to predict and avoid risks. For instance, in violent incidents caused by drinking, schools cannot predict every incident while students themselves are in the best situation to predict and avoid such incidents. This is the reason why the court applies the principle of "having no obligation" in the tort cases related to drinking. When both the university and students are aware of predictable risks, other factors should be considered to decide who should undertake the responsibilities 


\subsection{The Nature or Type of Risks or Damages}

Generally, the court is sensitive to the nature or type of risks and damages which may exert great influences on court decisions. For example, much attention has been paid to sexual abuse on female college students and corresponding regulations have been laid down. Comparatively, the risks caused by drinking will not call for much responsibility taken by the school.

\subsection{Adjacency}

As for this factor, the court often raises the following questions: Does the damage on a student happen within his relationship with the university? Does the way, time and place of this damage convince a person with rational thinking that it is the relationship between a university and its students that endows it with corresponding obligations? Therefore, when damages take place on campus or in dormitories, an adjacent relationship exists which is lessened when these damages happen due to drinking or incidents off campus. In fact, most tort litigation cases are based on disputes over this factor. Many disputes on whether there is special relationship between universities and students can be dealt with by considering this factor as well.

\subsection{Universities' Burden}

Currently, most universities' cost in safety imposes an impact on their educational quality and whether some students can afford higher education. Therefore, it is important for them to achieve a balance in this aspect considering insufficient cost does harm to education while excessive expense may deteriorate the quality of higher education. Meanwhile, the court has to be particularly cautious about giving any hint about unreasonably increasing expense in this aspect due to possible burden for universities and the influences on the achievement of education goals.

\subsection{Morality}

This factor is of particular importance for universities. Universities should give students the opportunity to be responsible for their actions and even interactions with others in order to promote the cultivation of their morality which cannot be realized with universities' full coverage of safely responsibilities. In this sense, universities are totally different from ordinary places for consumption in which consumers are only expected to be partially responsible for the common safety of the place. Differently, universities, not a typical consumer place, have no access to the same role. For the sake of safety, students cannot take campus safety for granted and allow strangers to violate dormitory safety rules. Only when students take the role of mutual constructor of a safe environment can common safety on campus be achieved. More importantly, universities promote students' awareness of self-responsibility and others' responsibility.

\subsection{Preventing Future Damages}

The court takes the prevention of future damages as one of the important factors, on which whether universities should be demanded to take the tort liability for students' personal damages will exert important influences as for the establishment of relevant institution to avoid future damages. Some universities adopt a wrong idea that the best way to restrict their responsibility is to be far away from students' life, especially those risks caused by drinking. Actually, such an attitude may give birth to greater risks due to students' failure to put themselves to the best situation caused by their immaturity, inexperience and faulty judgment. On the other hand, some damages can not be avoided or students themselves are the best to avoid their risks. In such situations, unpredictable risks will happen despite schools' safety measures.

\subsection{Insurance}

Although college students often participate in some activities to prepare for their future career, there is no compensation rule for their damages such as the insurance for workers' work injury. The compensation they can get from medical insurance, disability insurance and other limited resources is far from enough. Therefore, although not a necessary counterplea for liability, the insurance factor should be considered in some cases.

\section{Conclusion}

According to the above analysis, in the tort law, public policy serves as a method to balance social interests. The public policy factor considered by the court when dealing with the issue whether universities should take the safety ensuring obligation is a balance of universities, students and the whole society's interests. As for the university, their obligation of ensuring students' safety is a burden. If it is excessive, the public interests of the whole educational system will be influenced. As for students, such a fact cannot be overlooked that college students have their own judgment and relatively complete capacity for action and responsibility. It is mentioned by scholars that smooth relationship between universities and students should usually be a mutual sharing of responsibilities. Only in this way will the balance between the both sides and social interests be achieved.

In China, universities' responsibility for students' safety is mainly referred to in the Supreme People's Court's 
Explanation of Issues of Applicable Laws on Compensating Personal Damages, in which educational institutions such as schools and kindergartens are expected to fulfill the obligation of ensuring young people's safety. However, universities' obligation is not clearly stated. Similarly, this issue is not explored deeply among Chinese civil jurists. Even in some cases in which college students initiate legal proceedings against universities for their personal damages, only a simple judgment is given about whether universities violate their obligation of ensuring students' safety.

We hold the opinion that universities are different from the organizations conducting management activities and the relationship between universities and their students is different from that between primary and secondary schools and those young students. Therefore, the above regulations are not applicable in their cases. The practice in Britain and U.S. should be referred to in order to perfect the tort responsibility law in modern China. In legislation, due to public policy factors, the general obligation of ensuring students' safety gives way to that in some specific situations. In legal practice, when dealing with college students' prosecution against their schools for personal damages, more consideration about public policy should be turned to when deciding whether the university should take the responsibility in order to achieve the balance of universities, college students and social interests.

\section{References}

Li, Y. H. (2003). U.S. Tort Law. Law Press of China.

Peter, F. L. (1999). The Rise of Duty and the Fall of In Loco Parentis and Other Protective Tort Doctrines in Higher Education Law.

Shen, H., \& Zhou, Y. (2010). Student Damages, Liability of the Guardian and Violation of Safety Obligation. China Law Press.

Yang, L. (2003). The Second Book in the Series of New Tort Actions: Torts of Violating Safety Obligation. Law Service Times. 117.

Zhang, M., \& Song, Z. (2007). On Universities Obligation of Action. Universities' Tort Liability. Sun Yat-sen University Press.

Zhou, Y. (2008). On the Theories of Communication Safety Obligation. China People's University Press.

\section{(cc) $\mathrm{BY}$}

This work is licensed under a Creative Commons Attribution 3.0 License. 